\title{
What Is the Impact of Business Teacher's Physiognomies on Senior High Students' Academic Performance in the Kumasi Metropolis of Ghana?
}

\author{
Francis Atta Sarpong1 ${ }^{\circledR}$, Jianmin Wang1, Thomas Sarpong2, Gifty Osei-Mireku1 \\ ${ }^{1}$ School of Economics and Management, Anhui University of Science and Technology, Huainan, China \\ ${ }^{2}$ Department of Social Sciences, Atebubu College of Education, Atebubu, Ghana \\ Email: nanaipee@gmail.com
}

How to cite this paper: Sarpong, F. A., Wang, J. M., Sarpong, T., \& Osei-Mireku, G. (2020). What Is the Impact of Business Teacher's Physiognomies on Senior High Students' Academic Performance in the Kumasi Metropolis of Ghana? Open Journal of Business and Management, 8, 2761-2774. https://doi.org/10.4236/ojbm.2020.86171

Received: October 27, 2020

Accepted: November 24, 2020

Published: November 27, 2020

Copyright $\odot 2020$ by author(s) and Scientific Research Publishing Inc. This work is licensed under the Creative Commons Attribution International License (CC BY 4.0).

http://creativecommons.org/licenses/by/4.0/

(c) (i) Open Access

\begin{abstract}
Teachers' behavior, level of qualification, and years of experience play an important role in achieving students' academic success. The present study explored the effects of Business Teachers' Physiognomies (teachers' personality, qualification, and working experience) on Senior High School Business students' academic performance in the Kumasi Metropolis. The descriptive research design was employed in the study. Seven hundred and fifty (750) cost accounting, business management, and financial accounting high school students in the ten selected senior high schools in Kumasi Metropolis were involved in the study through a random sample technique. A standardized questionnaire was used in collecting data for the research. Moreover, three successive terms of the academic results of students were gathered to use for the study. The scores of students were analyzed using cross-tabulation for all three courses. Multiple linear regression was adopted to regress teachers' personality, qualifications, and working experience on students' academic performance. The study found that cost accounting, business management, and financial accounting teachers' personality, working experience, and qualification level have a significant positive effect on students' performance. It was recommended that schools' leaders ensure teachers are inspired to maintain their good work in enhancing business students' academic performance.
\end{abstract}

\section{Keywords}

Business Students, Teachers' Personality, Performance, Qualification, Years of Experience 


\section{Introduction}

Business teachers play an important role in students' acquisition of knowledge and skills by grooming and nurturing students with practical experience, skills, and value orientation (Khurshid, 2008; Omotayo, 2014). Teachers are builders who effectively teach and learn with their level of experience, personality, and qualification in the academic ladder. Teachers' characteristics found to be overriding in cross-country studies are related to attitude, capability, and working experience. Oyedeji (2000) asserted that teachers' efficiency is boosted with adequate knowledge and experience. The effect of teachers' physiognomies (both qualifications and demographic features) is essential for ensuring that teachers are most suited and able to enhance students' performance (Adeyemo, 2005).

It has been established in the literature that there is a significant relationship between teachers' physiognomies and students' academic performance (Ali, 2009). Researchers such as (Oloyede \& Amosuro, 2006; Kingdon, 2006; Agwanda, 2002) have found a statistically positive relationship between teacher's level of experience, qualification, and personality, and students' academic performance. The studies further emphasized that teachers possessing the right level of qualification can help their students achieve higher scores in the examination. Harris and Sass (2007) concluded that teachers with more experience are better teachers as their performance improves and is effective with added years on the job. Besides, teachers' personality is perceived to significantly positively affect students' performance in Business courses (Kheruniah, 2013; Arif, Baiju, \& Joseph, 2011).

There were also contradicting findings among researchers regarding the difference between students' performance in Cost accounting, Business management, and Financial accounting. There are no clearly defined paths as to students performed better in Accounting than in Management. Results of studies such as (Hopf \& Hatzichristou, 1999; Chen, 2000; Dee, 2006) suggested that students perform better in Business management than in financial accounting.

Business teachers (Cost accounting, Business management, and Financial accounting), just like all teachers' qualifications, years of teaching, and personality, should help students learn. However, the lack of qualified teachers has been eminent in many Senior High Schools, where Business teachers are not professionally qualified to teach (Koedel \& Betts, 2007). There is the presence of this problem in Senior High Schools in Ghana. In the field of Business, it seems that most teachers have adequate content pedagogy in the Business management than financial accounting as some teachers are unable to impart knowledge to students (Buddin \& Zamarro, 2009; Yeboah-Appiagyei, Osei-Tutu, \& Fentim, 2014).

There appears to be disputation in the literature regarding the relationship between Business teachers' physiognomies and students' academic performance. On one side, several studies found that teachers' personality, level of experience, and qualification significantly affect students' performance (Hanushek et al., 
2005; Khurshid, 2008; Zhang, 2008; Kosgei, Mise, Odera, \& Ayugi, 2013; Omotayo, 2014, Yeboah-Appiagyei, Osei-Tutu, \& Fentim, 2014). On the other hand, other studies have indicated that teachers' physiognomies do not significantly influence students' performance (Kimani, Kara, \& Njagi, 2013; Rowan, Correnti, \& Millwe, 2002). Hence, there seems to be no certainty regarding teachers' physiognomies on students' academic performance). As a result of this, researchers pursued determining the effects of Business Teachers' Physiognomies (teachers' personality, qualification, and working experience) on Senior High School students' academic performance in the Kumasi Metropolis. Specifically, the study addressed the hypothesis that teachers' physiognomies positively influence students' academic performance.

\section{Literature Review}

\subsection{Influence of Teachers' Physiognomies on Business Students' Academic Performance}

Wesh (2005) pointed out that research has shown that teachers' efficacy relies upon how effective they are able to display good behavior and experience in boosting students' academic performance. Since the late $18^{\text {th }}$ century, several researchers have tried establishing the relationship between the impact of teachers' personality, experience, and level of qualification on students' academic performance (Fraser, Walberg, Welch, \& Hattie, 1987; Krichbaum, 1992; Martin, 1979). As mentioned above, the researcher all proved to indicate either a positive or negative relationship between the teacher demographic variable and students' academic performance. Several literature reviews have discussed how teacher personality significantly affects students' academic performance (Wang, Haertel, \& Walberg, 1993).

Khurshid (2008) investigated the association between teachers' level of qualifications and their students' academic performance at the secondary school level using a sample size of eighty-seven teachers. It was found that there exists a strong positive relationship between teacher qualification and student's performance. Again, Zhang's (2008) investigated the effect of teachers' level of qualification, experience, and personality on students' performance also revealed a significant positive influence of teacher's level of qualification and personality on students' performance but a negative relationship between teachers' working experience and students' performance. Also, Kosgei, Mise, Odera and Ayugi (2013) revealed the relationship between teacher characteristics and students' academic performance. There was a significant negative relationship between teacher qualification, personality, and student academic achievement. This study also found a strong positive relationship between teachers' years of experience and students' academic performance. Yeboah-Appiagyei, Osei-Tutu, \& Fentim (2014) investigate the effect of teachers' experience on students' academic performance revealed a positive relationship between teaching experience and students' academic performance in financial accounting. 
Researchers such as (Quandahl, 2001; Welsh, 2005) have pointed out that teachers' personalities in the classroom tend to affect students' academic performance. They revealed that the type of approach teachers uses, how teachers perform in classrooms, and how teachers interact with students would impact student learning and achievement. The teacher's behavior in terms of classroom management, questioning style, engagement with students, and effectiveness in adopting student-centered teaching methods all, in the long run, affect students' performance in the classroom.

Omotayo (2014) carried out a descriptive survey study to investigate the relationship between teacher's characteristics (qualification, years of experience, personality) and students' academic performance in a business course. The study found a positive relationship between teacher characteristics (personality, work experience, qualification) and student performance. Kimani, Kara, and Njagi (2013) also investigated the relationship between teachers' demographic variables such as personality, level of qualification, and work experience on students' academic performance. The study's findings revealed no significant relationship between teachers' personality, qualifications, and experience in students' academic performance.

The same findings were revealed in Rowan, Correnti, and Miller (2002) study on the effects of teachers' level of qualification on students' academic performance. The above extensive review of literature governed the research hypothesis that was investigated using multiple regression analysis. This literature review was put into a conceptual model to oversee the study

\subsection{Conceptual Model and Hypothesis Proposal}

The conceptual model that will guide the study will look at teachers' characteristics in terms of qualification, experience, and personality affect Business students' performance over the years, focusing on their three successive term results. Based on an extensive literature review, the study's core model contains independent variables Business teacher physiognomies (Level of experience, qualification, and personality) and dependent variable Student academic performance in cost accounting, Business Management, and Financial accounting. This has been illustrated in Figure 1 .

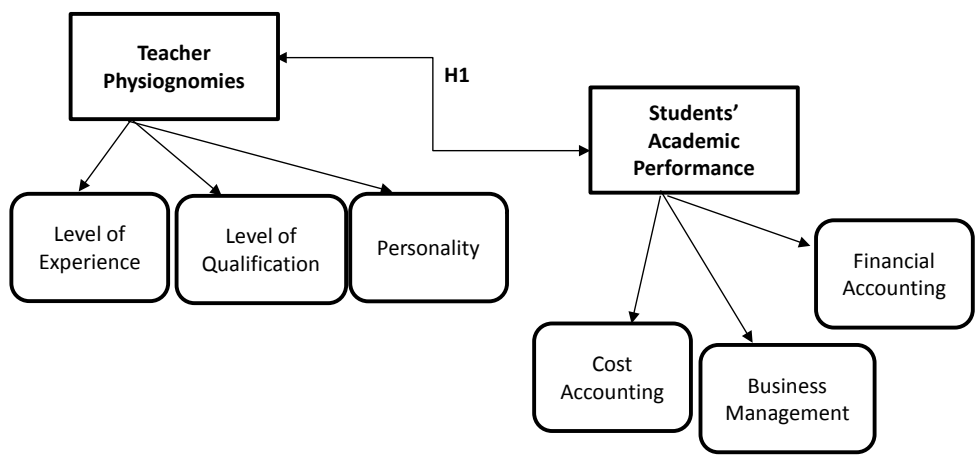

Figure 1. Conceptual model. 
The effect of teachers' level of experience, qualification, and personality on students' academic performance

\section{Research Hypothesis}

$H_{0}$ : Business teachers' physiognomies do not affect business students' academic performance in Cost accounting, Business management, and financial accounting in senior high school.

$H_{1}$ : Business teachers' physiognomies affect business students' academic performance in Cost accounting, Business management, and financial accounting in senior high school.

The hypothesis that governs the study was inspired by a literature review to investigate what other researchers have done regarding the topic under investigation.

\section{Methodology}

\subsection{Research Design}

The descriptive survey design was deemed appropriate for the study because it is versatile and practical, especially to educators in that they identify present conditions and point to present needs (Osuala, 2001). This will enable the researchers to investigate the effect of business teachers' physiognomies on students' academic performance.

\subsection{Sampling Technique}

The study population was all Business students who do Cost accounting, Business management, and financial accounting as elective courses of study and their respective teachers in senior high schools within Kumasi Metropolis. However, the accessible population was ten (10) cost accounting teachers, twenty (20) financial accounting teachers, and twenty-two (22) business management teachers and 1340 students in ten selected senior high schools. All Form One, Two students, and Three students were involved in the study. Seven hundred and fifty students (750) were involved in the study. The Table informs the researchers' decision to use this figure of Determining Sample Size proposed by Krejcie and Morgan (1970). The proportionate stratified sampling technique was adopted to govern the sample size of students selected in each school. Furthermore, simple random sampling was adopted to select 750 students from all the ten selected senior high schools. All of the teachers totalling 52 were involved in the study using the census method. As a result of the small population of business teachers from the ten selected schools, the Census method of sampling was adopted for this study. This was to ensure the validity of the responses provided in the survey. This is in line with the recommendation by Farooq et al. (2013) that the census method allows the researchers to have a penetrating view of a phenomenon under investigation.

\subsection{Data Collection Instrument}

A self-made questionnaire was used to collect information from the respondents. 
Two sets of questionnaires were designed for students and teachers. The self-made questionnaire was done after a comprehensive and extensive review of related literature. A five-point Likert-type scale was used for the instrument. Section A of the questionnaire implored information on the biographic data of the respondents. Section B also collected data on teachers' personality, qualifications, and working experience) from students. The teachers' questionnaire also covered areas such as their background information for Section A and Section B, looking at their personality, qualification, and work experience in detail. The three-term examination score was used to measure students' academic performance data on students' academic performance. All the questionnaires were analyzed using the Statistical Product for Social Sciences (SPSS) version 24. The analysis was computed into (frequencies and percentages) for the demographic information and multiple linear regression for hypothesis One of the study.

\subsection{Reliability and Validity of the Instrument}

The researcher's supervisors helped to determine the content validity of the instrument (questionnaire). The questionnaire was presented to him for their comments and suggestions. The suggestions they made were incorporated to refine the content of the instruments. Again, the instrument was then pilot-tested in five Senior High School (SHS) in the Accra Metropolis, which had similar characteristics as the schools selected for the study. The main purpose of the pilot-test was to validate the appropriateness of the items. Cronbach 0.86 was obtained to measure the internal consistency reliability of the questionnaire. The Cronbach value of 0.86 was deemed appropriate for the study as posited by Adamson \& Prion (2013), that a reliability coefficient of $(\geq 0.70)$ on a range of $(0$ - 1) indicates good internal consistency reliability.

\section{Empirical Research}

This section of the study presents and discusses the sample distribution statistics of the respondents of the survey. It again discusses business students' academic performance in cost accounting, business management, and financial accounting

\subsection{Research Sampling Distribution}

\subsubsection{Statistics on Demographic Information of Respondents}

The respondents' demographic information covers students' gender and level of experience, and the level of teachers' qualifications summarized from the two sets of questionnaires used in collecting data. Frequencies and percentages were adopted in presenting the results of information gathered from the respondents. Regarding the gender of the respondents' findings of the study revealed that (491) $65.5 \%$ of the students were male students while (259) $34.5 \%$ were female students. On the part of the teachers, it was also found that (32) $61.5 \%$ were male teachers while (20) 38.5\% were female teachers. Male students and teachers' responses dominated the study due to their representation in the survey compared 
to their counterparts. This has been clearly illustrated in Table 1 below.

From teachers' responses, (17) $33.7 \%$ of business teachers from the ten selected schools have been teaching between the duration 1 - 5 years. (30) 57.7\% of the teachers have been teachings between the duration 6 - 10 years. Finally, (5) $9.60 \%$ of the teachers have taught for more than 11 years. It can be concluded that the majority of the teachers involved in the study have been conducting business courses for a longer period. Therefore, they might be aware of how their personality, qualification, and experience affect students' performance in cost accounting, business management, and financial accounting.

Regarding the qualification level, it was found that (39) $75 \%$ and (13) $25 \%$ of the respondents respectively hold First degree, and Postgraduate degree. This implies that respondents have been trained adequately in content, methods, and principles that govern a particular subject: cost accounting, business management, and financial accounting.

\subsubsection{Academic Performance of Business Students}

This part of the study sought first to investigate business students' academic performance in cost accounting, business management, and financial accounting to establish a relationship with teachers' physiognomies. Researchers collected the academic achievement of all the students who participated in the study. The average examination scores for the three respective terms were collected from the individual school for analysis purposes. The cross-tabulation was used to analyze business students' academic performance in cost accounting, financial accounting, and business management. The results of the respondents are shown in Tables 2-4. This was done so that a fair idea of respondents' academic performance can be known to ascertain the relationship their performance has with their respective teachers' physiognomies in selected schools.

From Table 2, it is detected that 721 students scored 50 - 100 average scores in cost accounting, indicating very good performance in cost accounting. It was revealed that out of the 721 students, 393 of them had grade A1 (80 - 100) in cost

Table 1. Background information of respondents.

\begin{tabular}{cccc}
\hline Variable & Sub-scale & Student & Teachers \\
\hline \multirow{2}{*}{ Gender } & Male & F (\%) & F (\%) \\
& Female & $491(65.5)$ & $32(61.5)$ \\
Teacher Experience & $1-5$ years & $259(34.5)$ & $17(32.7)$ \\
& $6-10$ years & - & $30(57.7)$ \\
Level of Qualification & Above 11 years & - & $5(9.60)$ \\
& First Degree & - & $39(75)$ \\
& Postgraduate Degree & - & $13(25)$ \\
\hline
\end{tabular}

Source: Field Data (2019). 
Table 2. Cross-tabulation of average performance in cost accounting.

\begin{tabular}{ccccccccccc}
\hline \multicolumn{8}{c}{ Score Range of Students' Performance } \\
\hline Level & $80-100$ & $70-79$ & $60-69$ & $55-59$ & $50-54$ & $45-49$ & $40-44$ & $35-39$ & $0-34$ & Total \\
\hline One & 102 & 45 & 30 & 10 & 8 & 5 & 5 & 3 & 2 & 210 \\
Two & 150 & 89 & 59 & 9 & 1 & 5 & 7 & 0 & 0 & 320 \\
Three & 131 & 64 & 10 & 10 & 3 & 1 & 1 & 0 & 0 & 220 \\
Total & 383 & 198 & 99 & 29 & 12 & 11 & 13 & 3 & 2 & 750 \\
\hline
\end{tabular}

Scale: 50 - 100 (very good performance), below 50 (poor performance).

Table 3. Cross-tabulation of average performance in business management.

\begin{tabular}{cccccccccccc}
\hline \multicolumn{1}{c}{ Score Range of Students' Performance } \\
\hline Level & $80-100$ & $70-79$ & $60-69$ & $55-59$ & $50-54$ & $45-49$ & $40-44$ & $35-39$ & $0-34$ & Total \\
\hline One & 112 & 56 & 30 & 5 & 6 & 1 & - & - & - & 210 \\
Two & 200 & 82 & 30 & 6 & 2 & - & - & - & - & 320 \\
Three & 142 & 60 & 5 & 3 & 7 & 3 & - & - & - & 220 \\
Total & 454 & 198 & 65 & 14 & 15 & 4 & - & - & - & 750 \\
\hline
\end{tabular}

Scale: 50 - 100 (very good performance), below 50 (poor performance).

Table 4. Cross-tabulation of average performance for in financial accounting.

\begin{tabular}{cccccccccccc}
\hline \multicolumn{1}{c}{ Score Range of Students' Performance } \\
\hline Level & $80-100$ & $70-79$ & $60-69$ & $55-59$ & $50-54$ & $45-49$ & $40-44$ & $35-39$ & $0-34$ & Total \\
\hline One & 80 & 70 & 35 & 15 & 2 & 3 & 1 & 1 & 3 & 210 \\
Two & 56 & 78 & 89 & 59 & 16 & 5 & 7 & 4 & 6 & 320 \\
Three & 76 & 102 & 30 & 4 & 3 & 1 & 1 & 2 & 1 & 220 \\
Total & 212 & 250 & 154 & 78 & 21 & 9 & 9 & 7 & 10 & 750 \\
\hline
\end{tabular}

Scale: 50 - 100 (very good performance), below 50 (poor performance).

accounting. One hundred and two (102) were Form One student, 150 Form Two students, and 131 Form Three students. Out of 721, 198 students also had grade B2 ((70 - 79), even indicating very good cost accounting performance. It was again found that 99,29 , and 12 of the total students scored between B3 (60 - 69), C4 (55 - 59), and C5 (50 - 54), respectively. This infers that students performed very well in the cost accounting examination compared to their performance in business management and cost accounting.

Table 3 provides information on the average score of business students in a business management course; it is revealed that 746 students scored 50-100 average score in business management. This proves that the majority of the students performed well in Business management than in cost accounting. It was found that out of the 746 students, 354 of them had grade A1 (80 - 100). Of this, 112 were Form One students, 200 Form Two students, and 142 Form Three stu- 
dents. Out of 746, 198 students also had grade B2 ((70 - 79), indicating very good cost accounting performance. It was again found that 65,14 , and 15 of the total students scored between B3 (60 - 69), C4 (55 - 59), and C5 (50 - 54), respectively.

Moreover, the information in Table 4 revealed the average score of business students in one of the most feared courses by business students in Ghana; it is revealed that 715 students scored 50 - 100 average score in financial accounting. This is the course ranked last in terms of the number of students that performed well. However, a significant number of students had a higher average score. It was found that out of the 715 students, 212 of them had grade A1 (80 - 100). Of this, 80 were Form One student, 56 Form Two students, and 76 Form Three students. Out of 715, 250 students also had grade B2 ((70 - 79), indicating that most of the students had B2 in financial accounting compared to cost accounting and business management, where the majority had A1. It was again found that 154,178 , and 21 of the total students scored between B3 (60 - 69), C4 (55 - 59), and C5 (50 - 54), respectively.

\subsection{Regression Analysis of the Effect of Business Teachers Physiognomies on Students' Identify the Headings}

This section deals with the discussion of the results based on the data collected from the field. The data is used to answer the main research hypothesis that guided the study.

Hypothesis One: Business teachers' physiognomies affect business students' academic performance in Cost accounting, Business management, and financial accounting in senior high school

Multiple regression was used in regressing teachers' level of qualification, educational experience, and personality on business students' average academic performance for three terms in the elective business courses (cost accounting, business management, and financial accounting). Table 5 summarizes the analysis of data collected from both primary source (questionnaire) and secondary source (student' results). Three models were tested to see if the model could predict the academic performance of business students.

\section{Empirical Model}

The study implemented multiple linear regression in the study. Business teachers' level of qualification, teachers' years of experience, and teacher personality were regressed on students' academic performance for three terms: cost accounting, Business management, and financial accounting. This was done to help answer the research hypothesis that guided the study. The model took the form of;

$$
\mathrm{PS}=\beta_{o}+\beta_{1} \mathrm{QT}+\beta_{2} \mathrm{ET}+\beta_{3} \mathrm{PT}+\mathrm{E}
$$

PS = Academic performance of students, $\mathrm{QT}=$ Qualification of teachers

ET $=$ Teachers' years of experience, $\mathrm{PT}=$ Personality of teachers $\mathrm{E}=$ Error

Model 1: PS $=88.712+3.382 \mathrm{QT}+\mathrm{E}$ (Level of Qualification on Students academic performance 
Table 5. Effect of teachers physiognomies on students' academic performance.

\begin{tabular}{|c|c|c|c|c|c|}
\hline & \multirow{2}{*}{ Model } & \multicolumn{2}{|c|}{ Unstandardized Coefficients } & \multirow{2}{*}{$\mathrm{T}$} & \multirow{2}{*}{ Sig. } \\
\hline & & B & Std. Error & & \\
\hline \multirow{3}{*}{1} & (Constant) & 88.712 & 2.279 & 32.612 & 0.000 \\
\hline & QT & 3.382 & 0.612 & -2.377 & 0.000 \\
\hline & (Constant) & 81.136 & 3.154 & 21.565 & 0.000 \\
\hline \multirow[t]{3}{*}{2} & QT & 2.342 & 0.566 & -3.141 & 0.000 \\
\hline & ET & 2.375 & 1.424 & 2.411 & 0.009 \\
\hline & (Constant) & 65.555 & 9.229 & 6.871 & 0.000 \\
\hline \multirow{3}{*}{3} & QT & -2.313 & 0.636 & -3.251 & 0.000 \\
\hline & ET & 2.562 & 1.117 & $33 . .134$ & 0.001 \\
\hline & $\mathrm{PT}$ & 2.861 & 0.449 & 2.323 & 0.000 \\
\hline \multirow[t]{5}{*}{ Model 1} & $\mathrm{~F}=15.178$ & Model 2 & $\mathrm{~F}=8.412$ & Model 3 & $F=7.437$ \\
\hline & $\mathrm{df}=1$ & & $\mathrm{df}=2$ & & $\mathrm{df}=3$ \\
\hline & $p=0.000$ & & $p=0.000$ & & $p=0.000$ \\
\hline & $\mathrm{R}^{2}=0.043$ & & $\mathrm{R}^{2}=0.089$ & & $\mathrm{R}^{2}=0.100$ \\
\hline & $\mathrm{R}^{2}$ Change $=0.35$ & & $\mathrm{R}^{2}$ Change $=0.46$ & & $\mathrm{R}^{2}$ Change $=0.19$ \\
\hline
\end{tabular}

Source: Field Data (2019).

Information from Table 5 revealed that for Model 1, business teachers' level of qualification significantly ( $p=0.000)$ affects students' average academic performance. It can be detected that the level of qualification (independent variable) has a positive and significant effect on the dependent variable (students' academic performance). This means that an increase in teachers' level of qualification would increase students' academic performance. Hence, a $1 \%$ increase in qualification level would affect students' academic performance by cost accounting, business management, and financial accounting by the coefficient (3.382). The $R$ square of model 1 suggests that qualification elucidates $35 \%$ of students' educational performance disparity. This implies that other possible elements account for $65 \%$ of students' academic performance hence a need for model 2 to test to investigate the different aspects of independent variables that affect students' academic performance.

Model 2: $\mathrm{PS}=81.136+2.342 \mathrm{QT}+2.375 \mathrm{ET}+\mathrm{E}$ (Combining Level of qualification and Experience on students academic performance

Again, it was revealed in Model 2 that teachers' qualification level and the number of years teaching business management, cost accounting, and financial accounting seem to affect students' performance in those subject areas. Model 2 was significant $(p=0.000)$, indicating a substantial positive effect of Business teachers' level of qualification and years of experience on students' academic performance. Table 5 revealed that qualification has a significant positive impact on students' academic performance by its coefficient (2.342). In the same vein, 
teachers' working experience has a significant positive effect on students' academic performance. This infers that a $1 \%$ increase in teachers' working experience would positively increase students' performance by its coefficient (2.375). The R square of model 2 proposes that qualifications and years of experience explain $81 \%$ of students' academic performance variation. However, the introduction of the new variable (teachers' years of experience) contributed significantly. The teachers' years of experience alone explains this variation as a contribution to this model by $46 \%$. This implies that other factors explained the $19 \%$ of the students' academic performance variations in cost accounting, business management, and financial accounting. Hence, a need model 3 to fill in the gap exists.

Model 3: $\mathrm{PS}=65.555-2.313 \mathrm{QT}+2.562 \mathrm{ET}+2.861 \mathrm{PT}+\mathrm{E}($ Level of qualification, teacher experience and personality on students academic performance)

A final model was projected to forecast how teachers' physiognomies affect students' academic performance. Model 3 reveals that teachers' level of qualification, teachers' years of experience, and teachers' personalities give the impression to influence students' academic performance. It was found that these independent variables significantly $(p=0.000)$ affect the dependent variable (students' academic performance). The teacher level of qualification has a significant negative effect on students' academic performance from the model. This means that an increase in this independent variables would decrease students' academic performance; thus, a $1 \%$ increase in each of the two independent variables (level of qualification) would affect students' academic performance by the coefficient $(-2.313)$. However, teachers' years of experience and teachers' personalities have a significant positive effect on students' academic performance. This means that an increase in teachers' years of experience and teachers' personality would lead to an increase in students' academic performance; thus, a 1\% increase in teachers' years of experience and teachers' personality would increase students' academic performance by the coefficient (2.562 and 2.861) respectively. The $\mathrm{R}$ square for Model 3 shows that $19 \%$ of the variation in students' academic performance in financial accounting is accounted for by teachers' level of qualification, teachers' years of experience, and teachers' personality. This model predicts all-encompassing students' academic performance in terms of teachers' physiognomies. It can be implied that teachers' experience and personality positively influence students' academic performance. On the other hand, teachers' level of qualification negatively impacts students' academic performance in cost accounting, business management, and financial accounting.

There appears to be a connection between the findings revealed from this study and those done by scholars in the study field. In line with the results of (Khurshid, 2008; Kosgei, Mise, Odera, \& Ayugi, 2013; Omotayo, 2014; Yeboah-Appiagyei, Osei-Tutu, \& Fentim, 2014; Kimani, Kara, \& Njagi, 2013; Rowan, Correnti, \& Miller, 2002), the study revealed a significant positive influence 
that exists between teachers' physiognomies (qualification level, experience, and personality) and students' academic performance. This implies that teachers' physical characteristics can adequately and sufficiently affect students' performance in the classroom. Therefore, teachers' physiological makeup is a great determinant of students' success in business examination, such as cost accounting, business management, and financial accounting. The study results also contradict some researchers' findings that teachers' level of qualifications, experience, and personality do not influence students' academic performance.

\section{Conclusions and Recommendations}

It can also be concluded from the study findings that teachers' experience and a good personality can significantly and positively affect students' performance in class. For instance, students who are taught by experienced teachers who are knowledgeable in cost accounting, business management, and financial accounting and its methodology can perform well in their exams. However, teachers' qualification level has a significant negative effect on students' academic performance. Teachers with higher professional qualifications might be teaching student things beyond their limit, making it difficult for students to grasp understanding in their elective courses, such as cost accounting, business management, and financial accounting.

It is recommended to head of institutions responsible for educating business students to allow experienced teachers with a good personality to teach business students if possible, to prepare students adequately for their final exam. Moreover, teachers who hold a higher-level postgraduate degree should not be brought to teach students in senior high schools as they tend to teach things beyond the limit of the business students.

\section{Limitations}

Regarding the generalization of the study's findings, the fact remains that the relatively defined sample might not be large enough to permit the results' generality to all senior high schools in Ghana. As such, the findings of the study were generalized to only the population of the study. Research based on the questionnaire does not provide in-depth information (Johnson \& Christensen, 2012). This means that respondents were forced to decide on the items without allowing them room for their responses. Also, some respondents failed to answer questionnaires honestly. Moreover, there was difficulty in contacting students and teachers because of their time table structure. Some students were shy while answering the questionnaire because of the researchers' supervision. All those, as mentioned earlier, can lead to bias in study findings.

\section{Conflicts of Interest}

The authors declare no conflicts of interest regarding the publication of this paper. 


\section{References}

Adamson, K. A., \& Prion, S. (2013). Reliability: Measuring Internal Consistency Using Cronbach's a. Clinical Simulation in Nursing, 9, E179-E180.

https://doi.org/10.1016/j.ecns.2012.12.001

Adeyemo, D. A. (2005). Parental Involvement Interest in Schooling and School Environment as Predictors of Academic Self-Efficacy among Fresh Secondary School Student in Oyo State, Nigeria, Electronic Journal of Research in Educational Psychology, 5, 163-180.

Agwanda, J. A. (2002). A Study of Student Achievement in Kenya Certificate of Education in Kisumu. Unpublished M. Ed Thesis, Kisumu: Maseno University.

Ali, A. A. (2009). The Impact of Teacher Wages on the Performance of Students: Evidence from PISA. MPRA Paper No. 18252.

Arif, M., Baiju, A., \& Joseph, S. (2011). Attitude of College Students towards Physical Education and Sports. International Journal of Physical Education, 4, 45-52.

Buddin, R., \& Zamarro, G. (2009). Teacher Qualifications and Student Achievement in Urban Elementary Schools. Journal of Urban Economics, 66, 103-115.

https://doi.org/10.1016/j.jue.2009.05.001

Chen, Y. M. (2000). Feminization in Writing Pedagogy: A Study of Teacher's Gender at EFL University Composition Classrooms. National Chung Cheng University.

Dee, T. S. (2006). The Why Chromosome: How a Teacher's Gender Affects Boys and Girls. Education Next, 4, 69-75.

Farooq, B., Bierlaire, M., Hurtubia, R., \& Flötteröd, G. (2013). Simulation Based Population Synthesis. Transportation Research Part B: Methodological, 58, 243-263. https://doi.org/10.1016/j.trb.2013.09.012

Fraser, B. J., Walberg, H. J., Welch, W. W., \& Hattie, J. A. (1987). Syntheses of Educational Productivity Research. International Journal of Educational Research, 11, 147-252. https://doi.org/10.1016/0883-0355(87)90035-8

Hanushek, E. A., Kain, J. F., O’Brien, D. M., \& Rivkin, S. G. (2005). The Market for Teacher Quality (No. 11154). Cambridge, MA: National Bureau of Economic Research. https://doi.org/10.3386/w11154

Harris, D., \& Sass, T. R. (2007). Teacher Training, Teacher Quality and Student Achievement. Washington DC: The Urban Institute.

Hopf, D., \& Hatzichristou, C. (1999). Teacher Gender-Related Influences in Greek Schools. British Journal of Educational Psychology, 69, 1-18.

Johnson, B., \& Christensen, L. (2012). Educational Research: Quantitative, Qualitative, and Mixed Approaches. Thousand Oaks, CA: Sage.

Kheruniah, A. E. (2013). A Teacher Personality Competence Contribution to a Student Study Motivation and Discipline to Fiqh Lesson. International Journal of Scientific \& Technology Research, 2, 108-112.

Khurshid, K. (2008). A Study of the Relationship between the Professional Qualifications of the Teachers and Academic Performance of Their Students at Secondary School Level. World Academy of Science, Engineering and Technology, 38, 445-451.

Kimani, G., Kara, A., \& Njagi, L. (2013). Teacher Factors Influencing Students' Academic Achievement in Secondary Schools in Nyandarua County, Kenya. International Journal of Education and Research, 1, 1-14.

Kingdon, G. G. (2006). Teacher Certification Higher Pay and Academic Performance in 
India: A Pupil Fixed Effects Approach. A Global Poverty Research Group Project.

Koedel, C., \& Betts, J. R. (2007). Re-Examining the Role of Teacher Quality in the Educational Production Function. Vanderbilt: National Center on Performance Incentives.

Kosgei, A., Mise, J. K., Odera, O., \& Ayugi, M. E. (2013). Influence of Teacher Characteristics on Students' Academic Achievement among Secondary Schools. Journal of Education and Practice, 4, 76-82.

Krejcie, R. V., \& Morgan, D. W. (1970). Determining Sample Size for Research Activities. Educational and Psychological Measurement, 30, 607-610. https://doi.org/10.1177/001316447003000308

Krichbaum, K. E. (1992). The Relationship between Specific Teaching Behaviors and Achievement of Clinical Learning Outcomes by Baccalaureate Nursing Students.

Martin, W. R. (1979). Teacher Behaviors-Do They Make a Difference? A Review of the Research. Kappa Delta Pi Record, 16, 48-63. https://doi.org/10.1080/00228958.1979.10517647

Oloyede, D. O., \& Amosuro, O. Y. (2006). Teachers Qualification and Experience as Predictors of Their Job Performance. Journal of Educational Focus, 7, 1-12.

Omotayo, B. K. (2014). Teachers' Characteristics and Students' Performance Level in Senior Secondary School Financial Accounting. Journal of Empirical Studies, 1, 48-53.

Osuala, E. C. (2001). Introduction to Research Methods. Onitsha: Africana-FEP Publishers Ltd.

Quandahl, J. E. (2001). The Instructional Practices of Kindergarten Teachers: Effects on Student Achievement. Doctoral Dissertation, University of Houston.

Oyedeji, O. A. (2000). Effective Teaching of Mathematics. In S. Y. Erinosho, A. Adesanya, \& A. Ogunyemi (Eds.), Teaching Effectiveness in Nigerian Schools (Chap. 11, pp. 147-165). Ibadan: Sam Bookman Publishers.

Rowan, B., Correnti, R., \& Miller, R. J. (2002). What Large-Scale, Survey Research Tells Us about Teacher Effects on Student Achievement: Insights from the Prospectus Study of Elementary Schools. CPRE Research Reports.

Wang, M. C., Haertel, G. D., \& Walberg, H. J. (1993). Toward a Knowledge Base for School Learning. Review of Educational Research, 63, 249-294. https://doi.org/10.3102/00346543063003249

Welsh, K. A. (2005). Evaluating Teacher Effectiveness as Evidenced by the Professional Development and Appraisal System and Texas Assessment of Knowledge and Skills. Unpublished Doctoral Dissertation, College Station, TX: Texas A \& M University.

Yeboah-Appiagyei, K. A. T. E., Osei-Tutu, J., \& Fentim, D. B. (2014). Effects of Professional Qualifications of Financial Accounting Teachers on Academic Performance of Financial Accounting Students in Tamale Metropolis of Ghana. International Journal of Research in Social Sciences, 4, 83-91.

Zhang, D. (2008). The Effects of Teacher Education Level, Teaching Experience, and Teaching Behaviours on Student Science Achievement. PhD Dissertation, Logan, UT: Utah State University. http://digitalcommons.usu.edu/etd/155 